\title{
Project Management Practices and Performance of Women Economic Empowerment in Kiambu and Nairobi Counties, Kenya
}

\author{
Faith Kathure Kaluai (Corresponding Author) \\ School of Business, Kenyatta University \\ P. O. Box 43844-00100 Nairobi, Kenya \\ E-mail: kaluaif@gmail.com
}

\author{
Stephen Muathe \\ School of Business, Kenyatta University \\ P.O. Box 43844-00100 Nairobi, Kenya \\ E-mail: muathesm@yahoo.com
}

Received: April 10, 2020 Accepted: May 8, 2020 Published: August 24, 2020

doi:10.5296/bms.v11i2.17573 URL: https://doi.org/10.5296/bms.v11i2.17573

\begin{abstract}
The major concern regarding humanitarian program in the developing world is that they do not address the larger socio-economic challenges hence, not being sustainable. Even though, the application of project management practices in Africa shows positive project outcomes, the project management practices usage has been largely low. Hence, the study sought to determined the influence of project management practices on performance of Kenya's Women and Girls Economic Empowerment program performance in Kiambu and Nairobi counties, Kenya. Specifically, the study sought to determine the influence of stakeholder's involvement, project planning, risk management and monitoring and evaluation on program performance. The study was anchored on the stakeholder theory, prospect theory, contingency theory and realistic evaluation theory. This study adopted a census research design. The population targeted were staff of the CARE's Kenya's Women and Girls Economic Empowerment program comprising of project managers, project coordinators, quality control officers, government officials and beneficiary representatives. Semi-structured questionnaire was adopted for data collection. Descriptive statistics and multiple regression were utilized to
\end{abstract}


analyze the quantitative data. The study revealed that risk management contributes the most to Performance of Kenya's Women and Girls Economic Empowerment Program followed by stakeholder involvement, Project Planning and monitoring and evaluation respectively. The study recommends that there is need to come up with more rigorous strategies for making sure that appropriate processes of monitoring and evaluation are adhered to. Further, the program needs to emphasize on risk management linked to empowerment of economy and make staff education on mitigation strategies its priority.

Keywords: stakeholder's involvement, project planning, risk management, monitoring and evaluation

\section{Introduction}

In the current dynamic competitive world, programs have been compelled to constantly adjust to changing business conditions. Project Management contributes to competitive organizational strategy. It is seen as a key competency for associations that connects the outcomes of projects to their goals (Project Management Institute, 2015). Management of the project is a strategic capability that results in the connection to outcomes of projects to project goals (Project Management Institute, 2015).

With respect to firms that work on short-term projects for clients, Kerzner (2013) saw that project management should control the resources of a firm in a given activity applying limited cost and time for satisfactory performance and positive relationships with clients. Project management pursues a particular set of stages that characterize the work to be undertaken, the individual to carry out the work, the milestone, the individual to approve and audit the milestone and monitor and evaluate the milestone (Project Management Institute, 2015).

Project management includes conducting regular tasks that comprise the stages of project management of initiation and planning, execution, monitoring and control and Closing (Project Management Institute, 2015). The implementation of projects involves exercises that must be achieved within the limitations of risk, time, scope, budget, firm resources and quality (Atkinson, Waterhouse \& Wells, 2007). Firms are progressively putting more assets in projects, including new product development, process improvement and new services structure. However, research reveals that these projects neglect to meet the spending limit and time hindrances, or they neglect to fulfil client desires and targets (Sauser, Reilly \& Shenhar, 2009).

Project management vital constructs include the incorporation of planning, risk assessment, evaluation, monitoring, and engagement of stakeholders in the stages of project management. Monitoring and Evaluation (M\&E) of projects have progressively turned out to be key functions as projects grow to be complex and bigger. It involves assessing and detailing progress regarding goals. This activity is vital for stakeholders to comprehend the present condition of the project, undertaken activities, budget, forecast of the scope and the schedule. The cycle to monitor and evaluate comprise of: a plan; executing the plan; checking and 
recording the results; report the results, the parameters planned and variations; and make corrections with respect to the variations (Shrenash, Pimplikar \& Sawant, 2013). The capability of management through offering training on project management to the management employees prompts more income, reduced expense and improved firm regulatory environment and health in the sector. Internationally, $80 \%$ of management staff trusted that having Project management as a core capability helped them stay focused amid a recession.

Similarly, Mourshed, Chijioke and Barber (2010) report demonstrated that 58\% of 1400 worldwide officials gave priority to strong discipline in project management for future development. Stakeholders are people or Firms, for example, proprietors, sponsors, organizations that perform, or the general population, who are effectively engaged with the project or whose interests might be emphatically or adversely influenced by the project implementation or success.

According to KPMG (2013) report, the African Development Bank estimated that there is a need for $\$ 93$ billion for basic infrastructure in more than 50 cities with over 1 million populations. Yet the continent is still struggling with "overruns of cost, delays in construction and red tape are common" (KPMG, 2013, p. 27). While Africa relies on the management of projects to meet its development objectives, according to Ika, Diallo and Thuillier (2014), many projects are usually uncontrolled, unsuccessful, or poor project performance is dominant in Africa and that they have even dissatisfied its expansion.

Research on the practice of Project Management by Frimpong et al. (2013) in Ghana, on the project management practice in Africa, has revealed the causes of overruns for the delay and cost in Nigerian construction projects. Studies by Ika et al. (2014) acknowledged the communication role in the success of African projects. We are all aware of the issues on the management of African projects because a number of factors such as Corruption, bad government and inadequate capacity for (project) administration have been described as silent murders of African ventures and development (Collier, 2015; Moyo, 2017).

A survey carried out by Price Waterhouse Cooper pointed to the fact that $50 \%$ of the reasons why projects fail were due to poor practices for managing projects. In their findings, the public sector had the lowest project management levels compared to other sectors. Equally, the findings further state that project management practices use increases the likelihood of project success (Price Waterhouse Cooper, 2017). This supports the assertion by Martin (2013) that for a product to grow and succeed, one must learn how to make strategies and ideas a reality.

The Government of Kenya, through the Kenya Ports Authority management, impact on improving the port infrastructures in Mombasa. One of such heavy investment projects was Terminal Operating System like Kilindini Waterfront Automated Terminal Operations System (KWATOS) with an initial cost of KES 450million meant to improve efficiency in service delivery, although there is still uproar on inefficiencies within the Port of Mombasa. 
In the same way, Bass (2016) noticed that the measurement of performance of a program incorporates time, spending plan, security, quality and generally speaking customer fulfilment. All the criteria of performance ought to be straightforward and achievable, and once characterized, they ought to likewise be positioned through prioritization. A straight forward basis for estimating the performance of a program is everybody is engaged with it and hence responsibility is ensured. On the other hand, improbable criteria can cause disappointment on numerous programs in view of the measures that are not attainable, and this can produce low esteem in teams, influencing program performance and lastly, dissatisfaction among the stakeholders.

As per Abdi (2014), the project success in achieving its objectives is supported by the varied factors collaboration that, if examined and administered poorly, could lead to projects smashing as well as project obstruction from achieving the purposes set all over the prompting creation the non-performing project. The project execution, on the other hand, requires the activities carried out in order to comply with the project management program. This included organizing people and resources in line with the project management strategy, as well as incorporating and executing the work in progress (Omwaka \& Wanyoike 2016). Project Management Techniques are roles that project managers undertake to ensure success. These include designing, preparing, implementing, tracking and managing communication systems to ensure the progress of a project (Harvey, 2005). Management practices contribute to the coordination and management of resources so that resources perform any function necessary to complete the project in the designated environment, time and costs.

The involvement of stakeholders plays a key role in the management and performance of projects. Moodley (2012) indicates that the context in which projects are executed includes several actors, directly or indirectly, and that they are distinct in the degree to which they can affect the project. Stakeholder involvement occupies various areas in the cycle of the project and at various stages of the society and has many unique ways within a series of project inputs, initial expectations of the project, sharing of the project information, consulting, making decisions, corporations empowering each other. Baroudi, Olson and Ives (2016) indicate that engaging the user in the implementation of the project results in the use of the project as well as satisfying clients' needs.

Risk management seeks to identify, analyze and respond to risks by applying risk management principles and processes (Smith \& Jagger, 2010). Risk recognition includes identifying risks via thinking, benchmarking market and analysis of scenarios as well as workshops of assessment of risks that may impact the project. Risk quantification consists of risk evaluation as well as how various risks are linked, whereas designing a response to risk comprises taking proactive procedures against threats of risk. These include prevention, mitigation or acceptance. Risks have been identified and adequately mitigated, which affects the road infrastructure towards projects' performance. They included legal, technical, environmental, cultural, social as well as political risks. Managers of the project therefore have a duty to define and effectively manage risks. 
Monitoring and evaluation (M\&E) may help in recognizing and defining challenges as well as causes and suggesting possible resolutions. M\&E can have a strong influence on the success of the project, as insufficient information is available on it (Shapiro, 2011). UNDP (2009) notes that a series of complementary exercises include carrying out monitoring and assessments, and the main one of which is to devise a M\&E strategy that directs the entire exercise.

Kenya's Women and Girls Economic Empowerment program is a joint endeavor between the Kenya Government and CARE International Kenya. The primary goal of the program is to give a chance for change in a positive way. The activities of the program incorporate giving a pathway to young ladies to access and assume responsibility for profitable resources through training in business. The program then offers grants to trained program participants as a platform for young women to become financially active by providing opportunities that enable them to build sustainable livelihoods (CARE, 2017).

The program progresses in the direction of developing positive changes to Women and Girls as far as budgetary incorporation and financial strengthening activities that address needs of poor livelihoods, women that are insecure and young ladies limited by the absence of access to and power over profitable resources, services and refusal of rights living in an informal urban and rural settings. This is accomplished by developing the capabilities of poor societies through CAREs group savings and loans (GS\&L) strategy as a starting point. The implementers expand on the system of GS\&L to expedite a wide scope of intercessions that include: literacy in finances, sales agents in rural areas, development of micro-enterprises, connections to formal financial firms, models of poverty graduation and engagement in the market. The work is driven by inventive techniques in reaching the target market while using technology as leverage (CARE, 2017).

According to Mersland and Eggen (2007), most of the challenges in Kenya's Women and Girls Economic empowerment program are due to poor organization. Further, illiteracy among the beneficiaries is another challenge. This is further highlighted by Krishnair (2003), who in her study suggests that most of the beneficiaries in the program lack formal education. This then suggests that women should be given some form of education if they are to be used as a vehicle for economic empowerment.

The welfare monitoring survey indicates that the progress of women in Kenya's Women and Girls Economic Empowerment Program is unsatisfactory. The report suggests that general participation of the women in contribution to the economy is underrated. Social, economic and cultural factors take up their time, for instance, multiple roles in production and maintenance are time-consuming and exhausting women's ability to acquire skills is associated with overburdening household chores, impacting negatively on the performance of Kenya's Women and Girls Economic Empowerment Program. Thus, the program should strive to empower women without overburdening them further (GOK, 2015).

In Kenya, the number, magnitude and value of youth and women empowerment projects 
meant for socio-economic development like standard gauge railways have increased threefold over the last ten years (USAID, 2018). The project management practices awareness and use is still inadequate in developing countries and is the reason why projects are hardly completed on time, within the cost, quality and material specifications (Patunola-Ajayi, 2013; Nwachukwu \& Emoh, 2011). Consequently, increased implementation of the project management delivery system is a way to avoid such ills that have pervaded economic development programs for women and girls.

Economic empowerment projects remain important to policymakers in every institution of life both nationally and internationally, however, deprived programs of success and dishonest programs seemed to be mutually reciprocal scenarios (Gregg \& Ana, 2016). For instance, data from the Women Enterprise Fund program indicate that about 215,890 women have benefited from the program since its establishment in 2007. However, the low level of borrowing and repayment was a worry to stakeholders who felt that this might compromise the success of the program. The stakeholders felt that lack of proper planning and not being involved in program activities encouraged the downfall of the program, and hence economic empowerment was not attained (Rotich, 2014).

Kibera Power Women Group, which deals with textile and beadwork projects, have not succeeded in improving the welfare of its members. Majority of these projects have been in operation for many years, and have attracted funding from external and internal donors but has not translated into their economic and social empowerment due to poor project management practices. The failing plan has become a standard as demonstrated by Ika, Diallo and Thuillier (2014), with most programs running in the context of risk and uncertainty, external tension, unpredictable behavior, changing needs, limitless constraints and conflicting resources. All these affect the programs' success hence making the programs not to be skillful in the projected timelines, quality and budgets (Rotich, 2014). The little money that these women receive has not translated into their economic and social empowerment. This, therefore, means that though finance is a key factor in the performance of the groups, there are other underlying factors which negatively affect the performance of these groups. The impression, therefore, is proper governance structures translate into the empowerment of the group members. However, the status of women in Kibera does not seem to improve in line with these changes though the same area has quite a substantial number of women groups and NGOs working to improve womens' status (about 360 women groups with about 140 dealing with economic activities) (Kabeer, 2011)

Various empirical researches have concentrated on practices for managing project and projects performance. Millicent (2012) evaluated the effect of project management practices on firms of SMEs performance. Cheruiyot (2017) studied the effect of the information system implementation of project management on projects in the construction sector performance. In the same note, Muthomi (2015) conducted research on the practices of project management impact on the implementation of education projects that are donor-funded in Kajiado County. Nicholaus (2015) researched the impact of processes of managing project on results of 
infrastructure projects in the public sector at Telkom Kenya Limited. However, none of the referenced research concentrated on the utilization of project management practices in the Kenyan humanitarian sector. On the basis of this gap, this research tried to explore the influence of project management practices on performance of Kenya's Women and Girls Economic Empowerment Program in Kiambu and Nairobi counties, Kenya.

\subsection{Objectives of the Study}

To investigate the effect of project management practices on performance of projects under the Women and Girls Economic Empowerment program in Kiambu and Nairobi counties, Kenya.

\subsection{Specific Objectives}

i. To determine the influence of stakeholder's involvement on the performance of Care International's program Kenya's Women and Girls Economic Empowerment in Kiambu and Nairobi counties, Kenya.

ii. To establish the influence of project planning on performance of Care International's program Kenya's Women and Girls Economic Empowerment in Kiambu and Nairobi counties, Kenya.

iii. To assess the influence of risk management on the performance of Care International's program Kenya's Women and Girls Economic Empowerment in Kiambu and Nairobi counties, Kenya.

iv. To examine the influence of monitoring and evaluation on the performance of Care International's program Kenya's Women and Girls Economic Empowerment in Kiambu and Nairobi counties, Kenya.

\section{Theoretical Review}

The study was anchored on the following four theories; stakeholder theory, prospect theory, contingency theory and realistic evaluation theory.

\subsection{Stakeholder Theory}

Freeman, Wicks and Parmar (2004) proposed the stakeholder theory. The idea applies to incorporated frameworks, including nature and people. The stakeholder theory contends that project supervisors should settle on choices in order to assess the interests of all stakeholders in a project including money related petitioners, yet in addition representatives, clients, networks and administrative authorities (Gareis et al., 2009).

A firm's sustainability relies upon sustaining the relationship with stakeholders; an organization must consider and draw in not only investors, representatives, customers but all the included groups; thus, stakeholder connections must be the core principle in making of decisions by management. The whole stakeholder relationship is strategic for the long-haul achievement and survival of an organization; estimation of corporate achievement can't be 
restricted to the formation of significant worth for just a single stakeholder team (Clarkson,1995).

The supporters of stakeholder theory do not determine how to make the fundamental tradeoffs among these contending interests. They leave supervisors with a theory that makes it unimaginable for them to settle on intentional choices (Freeman, 2015). According to the stakeholder perspective on the firm, Donaldson and Preston (1995), an organization lasts in the event that it can assemble and keep up sustainable and relationships with all individuals from its stakeholders' systems. These connections are the basic resources that the management must oversee and they are a definitive wealth source for the firm.

This research was guided by the stakeholder theory that predicts that to improve performance; an association must think about the desires for its compelling stakeholders and endeavor to meet those desires. Stakeholders remain the fundamental drivers of an association; however, a balance should be made to guarantee that stakeholders' desires are in accordance with the firm's goals, mission, and vision. Therefore, this theory was essential in forming a basis on determining the stakeholder's involvement influence on Care International's program Kenya's Women and Girls Economic Empowerment performance in Kiambu and Nairobi counties, Kenya.

\subsection{Prospect Theory}

This theory was posited by Tversky and Kahneman (1979). It assists in making choices in uncertain situations. Decisions also include domestic disputes over value trade. This theory is designed to enhance comprehension, describing, and prediction for organizations and individuals in a world of uncertainty. The theory explains the development and assessment of these options in the process of making decisions. The theory of prospect is both descriptive and empirical. This focuses on two areas: the structure process and the evaluation phase (Bernheim\& Sprenger, 2019). The framing process explains how a decision can be shaped by the way a decision-maker is portrayed. This measurement process involves two parties: the values function as well as the weighing functions, in which the value function can be described in relation to the reference point in terms of gains and losses.

Prospect theory is utilized for making decisions in which the maker of decisions multiplies by the decision weight the value of every finding (Pachur, Schulte-Mecklenbeck, Murphy \& Hertwig, 2018). Risk is the explanation from the ambiguity associated with taking certain action to the risk for financial or economic loss or gain or delay. Risk management is therefore, essential in the management of risk-exposed projects to ensure that the project goals are fulfilled within the limits of the project. This theory underpins the risk management on the performance of Care International's program Kenya's Women and Girls Economic Empowerment in Kiambu and Nairobi counties.

\subsection{Contingency Theory}

The contingency theory of the structure of the organization delivers the main framework for the organizational design of the study (Donaldson \& Preston, 1995). The Contingency 
method is considered to be the dominant, theoretical, logical, open system model at the structural level of organizational theory research (Otley, 2016). The Conceptual Structural Model of Contingencies is considered the most successful. The systems are complex and need multiple management methods; the emergency strategy calls for conventional management theoretical and modeling processes (Joslin, 2019).

Organizations use this for control and assessment based on their configuration. Managers can track and respond using both the bottom-up and top-down feedback mechanisms in many ways. In some organizations, monitoring and evaluation may be automated. In the various stages of the project life cycle, companies also use various tracking and assessment methods.

Programs depend on the settings of the stakeholders and their actions. The key to the success of a program creativities is dependent on how well it manages relationships with key stakeholders, which includes clients, staff, vendors, families, contributors and others, who influence the achievement of the goals. This theory, therefore, forms a basis on the influence of project planning on performance of Care International's program Kenya's Women and Girls Economic Empowerment in Kiambu and Nairobi counties, Kenya.

\subsection{Realistic Evaluation Theory}

This theory was first published by Pawson in 1997, provides a guide to describe the effects, the way they are created and the importance of the different circumstances under which the involvements are made (Pawson \& Tilley 2004). Accurate assessment deals with 'What works for whom and in what situations and how?' (Pawson\& Tilley, 2004). The model helps the evaluator to consider the successful or unsuccessful aspects of an intervention and the contextual reasons required to duplicate an interference in other areas (Cohen, Manion \& Morison, 2008).

The realistic assessment attempts to define the appropriate circumstances that effectively allow intervention to learn how it produces results (Linsley, 2019), and can make a significant contribution in terms of understanding how the system deliverables are generated during monitoring and evaluation processes. The theory was utilized to clarify monitoring and evaluation variable and how it influences the performance of Care International's program Kenya's Women and Girls Economic Empowerment in Kiambu and Nairobi counties, Kenya.

\section{Method}

\subsection{Research Design}

This study used descriptive research design. The descriptive research is appropriate where the research tries to portray the attributes of specific groups, estimate the extent of individuals who have certain qualities and make forecasts (Cooper \& Schindler, 2011). The design was additionally applicable since it portrays situations as they exist without manipulation of study constructs, which was the basis of this investigation (Kothari, 2004).

\subsection{Target Population}




\section{Ml Macrothink}

The target population of this research were 118 staff of the CARE's Kenya's Women and Girls Economic Empowerment program comprising of project managers, project coordinators, quality control officers, government officials and beneficiary representatives.

\subsection{Sample Size Sampling Design}

The research conducted a census on the 118 staff of CARE's Kenya's Women and Girls Economic Empowerment program operating in Kiambu and Nairobi counties. Census sampling was the most appropriate since the target population was both accessible and small (Kothari, 2004).

\subsection{Data Collection Instrument}

The research was founded on primary data, which was gathered using questionnaires. The same was the most practical data collection instrument due to the applicability and practicability to the problem being researched and the population size. The same also saved on cost. The study took validity of the contents, which refers to the degree of adequate coverage of the subject in question by a measuring instrument. The instrument reliability was assessed utilizing Cronbach's Alpha Coefficient, which is the proportion of internal coefficient. A reliability of 0.70 at $\alpha=0.05$ significance level of confidence was acceptable. Changes were made appropriately in case a low Coefficient was derived so as to improve the instruments' reliability.

\subsection{Data Collection Procedure}

The researcher distributed the questionnaires to participants through the drop and pick-later strategy. The participants were given a time frame of a week to fill in the questionnaire. This was done to increase the rate of participants' response since the respondents were occupied with their work routines. Prior to leaving the questionnaires with the participants, the researcher explained its contents to the participants. The process took two weeks.

\subsection{Data Analysis and Presentation}

Data gathered was coded and grouped into various segments to encourage better assessment. Content analysis was used for analyzing qualitative data (Nsubuga, 2006). Descriptive statistics were utilized to analyze quantitative data. Multiple linear regression was adopted to show the significance of each independent variable. A t-test was conducted to show the significance of each independent variable. The multiple regression analysis model specification was as follows; $Y=\alpha+\beta_{1} X_{1}+\beta_{2} X_{2}+\beta_{3} X_{3}+\beta_{4} X_{4}+\varepsilon$ where; $\varepsilon=$ error term, $\beta=$ coefficient of the independent variable $\left(\beta_{1-4}=\right.$ regression coefficient $)$ and $\alpha=$ constant.

$\mathrm{Y}=$ is the dependent variable (performance of Kenya's Women and Girls Economic Empowerment Program)

$\mathrm{X}_{1}=$ Stakeholder involvement;

$\mathrm{X}_{2}=$ Project planning; 
$\mathrm{X}_{3}=$ Risk management;

$\mathrm{X}_{4}=$ Monitoring and evaluation .

\section{Research Findings and Discussions}

\subsection{Response Rate}

The study had a sample size of 118 respondents who were to fill and return the questionnaires, and only 60 of the respondents returned the questionnaires duly filled in contributing to a response rate of $96.8 \%$. This response rate was sufficient and representative and adequate for data analysis and statistical reporting.

\subsection{Reliability Statistics}

Reliability means the degree to which reliable and consistent results are produced through an assessment method. Test and internal consistency were used in this analysis. The alpha coefficient of Cronbach has been defined. The results were as shown in Table 1.

Table 1. Reliability statistics results

\begin{tabular}{lccc}
\hline & $\begin{array}{c}\text { Cronbach's } \\
\text { Alpha }\end{array}$ & $\begin{array}{c}\text { Cronbach's Alpha Based on } \\
\text { Standardized Items }\end{array}$ & $\begin{array}{c}\text { N of } \\
\text { Items }\end{array}$ \\
\hline $\begin{array}{l}\text { Stakeholder's } \\
\text { involvement }\end{array}$ & 0.732 & .757 & 4 \\
Project planning & 0.726 & .735 & 4 \\
Risk Management & 0.714 & .726 & 4 \\
Monitoring And & & .716 & 4 \\
Evaluation & 0.707 & & 4 \\
Average & 07198 & .7335 & 4 \\
\hline
\end{tabular}

From the results, it was established that the Cronbach alpha coefficients were higher than 0.7 , which was provided for by the study for all the four study variables. The Cronbach alpha coefficients for the respective variables were; stakeholder's involvement (0.732), project planning (0.726), risk management (0.714) and monitoring and evaluation (0.707). The higher than 0.7 Cronbach alpha coefficients implied that there was internal consistency for the respective four variables hence high reliability among the variables.

\subsection{Regression Analysis}

The study needed to confirm the relationship between independent and dependent variables 
and multiple regression analysis was used for this purpose. The findings for the model summary are illustrated in Table 2 .

Table 2. Model summary

\begin{tabular}{ccccc} 
Model & R & R Square & Adjusted R Square & Std. Error \\
\hline 1 & 0.824 & 0.679 & 0.664 & 0.348
\end{tabular}

Table 2 shows that $r=0.824$ which implies that the four independent variables have a strong relationship with the performance of Care International's program Kenya's Women and Girls Economic Empowerment in Kiambu and Nairobi counties, Kenya. The coefficient of determination given by $\mathrm{R}^{2}$ is 0.679 , indicating that the four independent variables explain 67.9\% of the variations in the Performance of Kenya's Women and Girls Economic Empowerment Program while other variables not covered in the study were represented by $32.1 \%$.

The ANOVA was utilized to check the argument that the independent variables (project management practices) and the dependent variable (performance of Kenya's Women and Girls Economic empowerment program for Care International) are not significant. The results for ANOVA are illustrated in Table 3.

Table 3. ANOVA

\begin{tabular}{lccccc}
\hline Model & Sum of Squares & df & Mean Square & F & Sig. \\
\hline Regression & 23.039 & 4 & 5.760 & 45.998 & $.000^{\mathrm{b}}$ \\
$\begin{array}{l}\text { 1 Residual } \\
\text { Total }\end{array}$ & 10.894 & 87 & 0.125 & & \\
& 33.933 & 91 & & & \\
\hline
\end{tabular}

Source: Survey Data (2019)

The $\mathrm{p}$-value is 0.000 that is not greater than $p=0.05$ thus the model is significant statistically in forecasting how the four project management practices influence the performance of Care International's Program Kenya's Women and Girls Economic Empowerment. The F critical (45.998) at $5 \%$ level of significance was greater than the F calculated (value $=2.476$ ), and $\mathrm{p}<0.000<0.05$ this shows that the overall model was significant in predicting project management practices influencing the performance of Care International's Program Kenya's Women and Girls Economic Empowerment.

The regression model on which the study was based; $Y=\alpha+\beta_{1} X_{1}+\beta_{2} X_{2}+\beta_{3} X_{3}+\beta_{4} X_{4}+\varepsilon$ was transformed into $\mathrm{Y}=1.720+0.528(\mathrm{RM})+0.424(\mathrm{~S} \mathrm{I}) \mathrm{I}+0.260(\mathrm{PP})+0.234(\mathrm{M} \& \mathrm{E})+\epsilon$. 
The study $\mathrm{Y}$ is the dependent variable (Performance of Kenya's Women and Girls Economic Empowerment Program), $\alpha=$ Constant; $\beta 1, \beta 2, \beta 3, \beta 4=$ Beta Coefficients; $\mathrm{RM}=$ Risk Management; $\mathrm{SI}=$ stakeholder involvement; $\mathrm{PP}=$ Project Planning and $\mathrm{M} \& \mathrm{E}=$ monitoring and evaluation. The regression coefficients are as presented in Table 4.

Table 4. Regression coefficients

Coefficients $^{\text {a }}$

\begin{tabular}{|c|c|c|c|c|c|c|c|}
\hline \multirow[t]{2}{*}{ Model } & \multicolumn{2}{|c|}{$\begin{array}{l}\text { Unstandardized } \\
\text { Coefficients }\end{array}$} & \multirow{2}{*}{$\begin{array}{c}\text { Standardized } \\
\text { Coefficients } \\
\text { Beta }\end{array}$} & \multirow[t]{2}{*}{$\mathrm{t}$} & \multirow[t]{2}{*}{ Sig. } & \multicolumn{2}{|c|}{$\begin{array}{c}95.0 \% \text { Confidence } \\
\text { Interval for B }\end{array}$} \\
\hline & B & Std. Error & & & & $\begin{array}{l}\text { Lower } \\
\text { Bound }\end{array}$ & $\begin{array}{l}\text { Upper } \\
\text { Bound }\end{array}$ \\
\hline (Constant) & 1.720 & .413 & & 4.161 & .000 & .891 & 2.548 \\
\hline Project planning & .260 & .096 & .235 & 2.703 & .007 & .067 & .452 \\
\hline $\begin{array}{l}\text { monitoring and } \\
1 \text { evaluation }\end{array}$ & .234 & .070 & .203 & 3.321 & .009 & .093 & .375 \\
\hline $\begin{array}{l}\text { Risk } \\
\text { Management }\end{array}$ & .528 & .086 & .487 & 6.131 & .000 & .355 & .700 \\
\hline $\begin{array}{l}\text { stakeholder } \\
\text { involvement }\end{array}$ & .424 & .089 & .390 & 4.778 & .000 & .601 & .246 \\
\hline
\end{tabular}

At 5\% level of significance, all the four project management practices were statistically significant as their $p$-value is within the recommended thresholds of $(p<0.05)$.From the findings, positive effect on Kenya's Women and Girls Economic Empowerment Program performance were found on all the four project management practices, that is, Management of Risk; involvement of stakeholder; Project Planning and monitoring and evaluation with the coefficient of regression values: $\beta 0=1.720, \beta 1=0.528, \beta 2=0.424, \beta 3=0.260$ and $\beta 4=0.234$ respectively.

Risk Management had a $\beta 1=0.528$, and a $\mathrm{p}=0.000$ revealed that there was a positive statistically significant association amongst management of risks and Kenya's Women and Girls Economic Empowerment Program performance. This is accordance to Wanyonyi (2015) who argued that risk could be defined in projects as the likelihood of a program objective occurrence which is likely to have an effect and is measured in terms of probability and consequences thus risk management activities have a positive impact on timely program 
delivery. Also, in relation to the findings, Kisaka and Musomi (2017) mention that Projects are filled with uncertainties and failure to properly recognize or handle these uncertainties can lead to serious issues and problems quickly.

Stakeholder involvement had a $\beta 2=0.424$ and a $\mathrm{p}=.000$ indicated that there was a negative statistically significant relationship between Stakeholder involvement and performance of Kenya's Women and Girls Economic Empowerment Program. These findings are in line with Adan (2012), who noted that in a project environment, these stakeholders are usually numerous, and can vary significantly in the degree of influence in both directions. Further, Njogu (2016) asserted that the number and nature of stakeholders would vary with the life of the project, it would, therefore, make sense to carry out the review of identification throughout the project.

Project Planning had a $\beta 3=0.260$ and a $\mathrm{p}=0.007$ showed that Project Planning and performance of Kenya's Women and Girls Economic Empowerment Program have a negative and statistically significant relationship between. In Nzioka (2017), the daily planning analysis should be more focused on the task rather than the level of activity. This strategy is intended to improve the project preparation and lead to better results. Also, Mkutano and Sang (2018) asserted that comprehensive planning that involved the participation of stakeholders enhanced sustainability scores.

Monitoring and evaluation had a $\beta 4=0.234$ and $\mathrm{p}=.009$ indicated that there was a negative statistical significant relationship between monitoring and evaluation and performance of Kenya's Women and Girls Economic Empowerment Program. Phiri (2015) supported these findings as he stated that Monitoring and Evaluation Practices is a vital project lifecycle stage and magnificent practice of management. Moreover, the findings were consistent with Waithera and Wanyoike (2015) who mentioned that frameworks for monitoring and evaluation are envisioned for advising managers of the projects if the implementation is as per the plan and if the corrective activity is expected for modification of project strategies of execution.

The findings imply that risk management contributes the most to Performance of Kenya's Women and Girls Economic Empowerment Program followed by stakeholder involvement, project planning and monitoring and evaluation respectively. The findings are similar to Nicholaus (2015), who noted that established project management practices and program performance among government-financed projects are significantly related. The study determined that the key project management practices found to have had a significant influence on program performance were; planning for risk management involvement of stakeholders as well as monitoring and evaluation.

\section{Discussion}

From the findings, the study deduced that the most significant project management practice influencing Performance of Kenya's Women and Girls Economic Empowerment Program was the risk management; followed by stakeholder involvement; project planning and 
monitoring and evaluation

\subsection{Stakeholder's Involvement and Program Performance}

Stakeholder's involvement was concluded to have a positive and significant influence on the performance of CARE International's program Women and Girls Economic Empowerment in Kiambu and Nairobi counties, Kenya. The study concluded it is very necessary that stakeholders engage in project planning and execution on project proposals by suggesting that stakeholders participate fully in the project management process.

From the finding that stakeholder involvement helps in creating buy-in and ownership of the project, the study concluded that the project ownership promotion ways and stakeholders sustainability includes: processes formulation and implementation that satisfies each project stakeholder, focused to stakeholders so as to fulfil those engaged or influenced and making sure there is full the stakeholders' engagement.

\subsection{Project Planning and Program Performance}

The study concludes that project planning influenced the performance of CARE International's program Women and Girls Economic Empowerment in Kiambu and Nairobi counties, Kenya significantly. From the finding that resources and time of completion of the project influence the planning of a project, the study concluded that the program to be achieved throughout the program established clear objectives and goals. The study further deduced that planning makes sure employees as well as other stakeholders, are working towards common goals, based on consensus around intended findings and examined and accustomed the programs' direction in response to a varying environment. This is attributed to the fact that it was revealed that project planning as well as designing results to program effectiveness.

\subsection{Risk Management and Program Performance}

Risk Management and CARE International's program Women and Girls Economic Empowerment performance of in Kiambu and Nairobi counties, Kenya were concluded to be positively and significantly related. From the finding that project management tools and Techniques (PMTT) contributes significantly to project implementation success, the study concluded that a documented plan for reporting events might pose potential risks on the delivery of services. Such risks include fraud, terrorism funding, customer turnover and third party ownership of the platform.

The study found out that lack of project risk management skills has contributed to delay and failure of programs, thus the study concluded that to mitigate risk programs should employ: training and awareness, close monitoring, follow-ups and continuous system tests.

\subsection{Monitoring and Evaluation and Program Performance}

Monitoring and evaluation were concluded to have a positive and significant influence on the performance of CARE International's program Women and Girls Economic Empowerment in Kiambu and Nairobi counties, Kenya. From the finding that the program has effective project 
monitoring plans, tools and processes exist, this study concludes that monitoring and evaluation is a key performance determinant in that it assists in monitoring activities and offers action courses when things are not moving on as planned.

The study further concluded that monitoring and evaluation play a role in backing effective management decisions since it was found that it offers decision-making information. A successful M\&E knowledge decision will boost the programs' efficiency. Further, it was concluded that through robust monitoring and evaluation systems institutionalized in the program implementation, the program planning and decision making was evidence-driven, increasing the chances of meeting the set targets. Similarly, it was concluded that monitoring and evaluation ensured that risks that kept coming from time to time were effectively managed increasing program performance.

\section{Recommendation}

The study recommended that more stringent measures should be put in place to ensure proper monitoring and evaluation processes are followed. These measures include a clear report and feedback follow-up, consistent stakeholder contact and the lessons learned from past experience. In order to strengthen successful practices and prompt corrective action, it should create awareness of its recorded monitoring and assessment plans and processes. This also leads to the creation of a system culture that is part of the organization's daily activities.

The program should emphasize the need for managing risks linked to empowerment of economy and make staff education on mitigation strategies its priority. The study recommended the system to provide continuous monitoring and to establish mitigation strategies because control of risk increases the chances of programs achieving their objectives. The study found that procedures for risk assessment are not well developed and performed. The study suggests that the audit department lead this position by establishing a system that guides risk assessment processes. Risk assessment processes can enhance risk mitigation through the minimization of threats and opportunities.

The Government should improve on the marketing of the program by encouraging the women and girls to join organized marketing systems like cooperatives and registered groups. The project team should thus develop marketing strategies to ensure that word is spread beyond their borders. Proper marketing may also inform the community of the advantages of the program in empowering the economy. The study suggests that the program team and its managers periodically practice, so they are trained with relevant skills to achieve better program results. The study concluded that the problems and way for the future are not addressed by all stakeholders in Kenya's Women and Girls Economic Empowerment in Kiambu and Nairobi counties, Kenya.

The study recommended that the system define measures to ensure active participation by all stakeholders in the solution of problems and strategies. This encourages the control of these approaches and their sustainability. The system, in which interactions, ideas and views can be taken from either side, should follow a model of engaging stakeholders that creates a 
constructive bi-directed mechanism between the program. This commitment allows the program to change the usual management practice of its projects in order to include changes which improve its performance.

The study suggests that the project management team or the Committee regularly assess stakeholder interests, thus improving its buy-in and minimizing intergroup conflicts. The study further suggests that stakeholders be active in all pre-and start-up meetings and that their perspectives are included in the planning and implementation process. This will make the program more appropriate and provide a way to build a connection between social investment and more ideas.

\section{References}

Abdi, H. (2014). An investigation of factors influencing performance of nongovernmental projects in Kenya: a case of Garissa County. Retrieved from http://erepository.uonbi.ac.ke/11295/74059

Antill, V. (2014). Making projects a success. Communications of the ACM, 43(3), 57-61.

Atkinson, A. A., Waterhouse, J. H., \& Wells, R. B. (2007). A stakeholder approach to strategic performance measurement. Sloan Management Review, 38(3), 25-37.

Baroudi, J. J., Olson, M. H., \& Ives, B. (2016). An Empirical Study of the Impact of User Involvement on System Usage and Information Satisfaction. Communications of the ACM, 29(3), 232-243. https://doi.org/10.1145/5666.5669

Bass, B. M. (2016). Leadership and Performance beyond Expectations. New York: The Free Press.

Bernheim, B. D., \& Sprenger, C. (2019). Direct tests of cumulative prospect theory. Available at SSRN 3350196. https://doi.org/10.2139/ssrn.3350196

CARE. (2017). Kenya's Women and Girls Economic Empowerment Program bulletin. Nairobi Kenya.

Chandra, H. P., Putu, A. W. I., \& Kaming, P. F. (2012). Model of stakeholder influence on project success, an important finding from construction project in East Java. International Journal of Academic Research, 4(2).

Clarkson, K. (1995). Introducing stakeholder management. Construction stakeholder management, 1 .

Cohen, L., Manion, L., \& Morison, K. (2008). Research Methods in Education. London: Routledge Falmer.

Collier, P. M. (2015). Costing Police services: the politicization of accounting. Critical Perspectives on Accounting, 17, 57-86. https://doi.org/10.1016/j.cpa.2004.02.008

Cooper, D., \& Schindler, P. S. (2011). Business research methods (8th ed). New Delhi: Tata McGraw-Hill Publishing Company. 
Donaldson, K., \& Preston, H. (1995). Stakeholder analysis for R\&D project management. R\&D Management, 32(4), 301-310. https://doi.org/10.1111/1467-9310.00262

Freeman, R. E., Wicks, A. C., \& Parmar, B. (2004). Stakeholder theory and the corporate $\begin{array}{llll}\text { objective } \quad \text { revisited. } & \text { Organization } & \text { science, } & \text { 15(3), }\end{array}$ https://doi.org/10.1287/orsc.1040.0066

Frimpong, Y., Oluwoye, J., \& Crawford, L. (2013). Causes of delay and cost overruns in 1156 construction of groundwater projects in a developing countries: Ghana as a case study. Journal of Project Management, 21, 321-326. https://doi.org/10.1016/S0263-7863(02)00055-8

Gareis, K., Silvius, A. G., \& Schipper, R. (2009). A maturity model for integrating sustainability in projects and project management. In 24th World Congress of the International Project Management Association (IPMA) Istanbul, Turkey.

GoK. (2015). Budget Statement For the Fiscal Year 2015/2016 (1st July - 30th June) by Mr. HENRY K. ROTICH Cabinet Secretary for The National Treasury.

Gregg, A., \& Ana, L. (2016). A Framework for Exploring the Relationship Between Project Manager Leadership Style and Project Success. The international journal of management, $1(1), 1-19$.

Harvey, A., \& Reed, R. (2006). Community Managed Water supplies in Africa: stainable or dispensable? Community Development. https://doi.org/10.1093/cdj/bs1001

Harvey, L. A. (2005). Project portfolio management: a practical guide to selecting projects, managing portfolios, and maximizing benefits. New Jersey: John Wiley \& Sons.

Ika, A., Diallo, A., \& Thuillier, D. (2014). Critical success factors for World Bank projects: An empirical investigation. International Journal of Project Management, 30(2), 105-116. https://doi.org/10.1016/j.ijproman.2011.03.005

Joslin, R. (2019). Project Management Methodologies, Project Success, Project Governance, Contingency Theory, Agency Theory, and Stewardship Theory. In Project Management Methodologies, Governance and Success, 17-30. Auerbach Publications. https://doi.org/10.1201/9780429071416-3

Kabeer, N. (2011). Contextualising the Economic Pathways of Women's Empowerment: Findings from a MultiCountry Research Programme. Pathways Policy Paper. Brighton: Pathways of Women's Empowerment RPC.

Kerzner, H. R. (2013). Project management: a systems approach to planning, scheduling, and controlling.

KIPPRA. (2002). Kenya Institute for Public Policy Research and Analysis. Working Paper. Nairobi.

Kisaka, S. E., \& Musomi, B. (2017). The effect of risk management on performance of investment firms in Kenya. ORSEA JOURNAL, 5(1). 
Kothari, C. R. (2004). Research methodology: methods and techniques (2 $2^{\text {nd }}$ ed.). New Delhi. New Age International (P) Limited.

KPMG. (2013). The KPMG survey of corporate responsibility reporting 2013.

Linsley, P. (2019). Realistic Evaluation as both a science and as a methodology. Pielegniarstwo XXI wieku/Nursing in the 21st Century. https://doi.org/10.2478/pielxxiw-2019-0025

Martin, S. (2013). Project Management Pathways. APM Publishing Ltd.

Mersland, R., \& Eggen, O. (2007). You Cannot Save Alone. Financial and Social mobilisation in Savings and Credit Organisation. Volumes 8-20080f NORAD Report. https://doi.org/10.2139/ssrn.1032247

Mkutano, S. M., \& Sang, P. (2018). Project management practices and performance of non-governmental organizations projects in Nairobi city county, Kenya. International Academic Journal of Information Sciences and Project Management, 3(3), 1-22.

Moodley, K. (2012). Project Stakeholders, Engineering Project Management. Edited by N. J. Smith, 2nd Edition. Blackwell Publishing.

Mourshed, M., Chijioke, C., \& Barber, M. (2010). How the world's most improved school systems keep getting better. London: McKinsey \& Company. https://doi.org/10.17323/1814-9545-2011-2-5-122

Moyo, D. (2017). Dead Aid: Why Aid is Not Working and How There Is a Better Way for Africa. New York: Farrar, Straus, and Giroux.

Muthomi, N. M. (2015). Influence of project management practices on implementation of donor funded education projects in Kajiado County, Kenya. Doctoral dissertation, University of Nairobi.

Nsubuga, E. H. K. (2006). Fundamentals of Education Research. Kampala, Uganda. K Publishers (U) Ltd.

Nwachukwu, C., \& Emoh, F. I. (2011). Building construction project management success as a critical issue in real estate development and investment. American journal of social and management sciences, 2(1), 56-75. https://doi.org/10.5251/ajsms.2011.2.1.56.75

Nzioka, C. (2017). Role of Project Management Planning On Project Success In Kenya: A Case Of Kenya Power Infrastructure Development Projects. International Journal of Novel Research in Engineering and Science, 4(1), 36-43.

Omwaka, N., \&Wanyoike, D. (2016). Analysis of factors affecting the implementation of non-governmental organization projects in Nakuru County, Kenya. International Journal of Economics, Commerce and Management United Kingdom, 4(5), 851-870.

Otley, D. (2016). The contingency theory of management accounting and control: 1980-2014. Management accounting research, 31, 45-62. https://doi.org/10.1016/j.mar.2016.02.001 
Pachur, T., Schulte-Mecklenbeck, M., Murphy, R. O., \& Hertwig, R. (2018). Prospect theory reflects selective allocation of attention. Journal of Experimental Psychology: General, 147(2), 147. https://doi.org/10.1037/xge0000406

Patunola-Ajayi, B. J. (2013). Infrastructure Development and Economic Empowerment in Nigeria. In Being a conference paper at the Nigerian Institution of Estate Surveyors and Valuers.

Pawson, R., \& Tilley, N. (2004). Realistic Evaluation. The Social Science Journal, 41(1) https://doi.org/10.1016/j.soscij.2003.10.017

Phiri, B. (2015). Influence of monitoring and evaluation on project performance: A Case of African Virtual University, Kenya. University of Nairobi.

Price Waterhouse Coopers. (2017). Annual report on project cycle management. PWC Press Kenya.

Project Management Institute. (2015). Pulse of the Profession: Capturing the Value of Project Management.

Rotich, J. (2014). Projects Critical Success Factors: Empirical Study of Non-Governmental Organizations in Nairobi County, Kenya. International Journal of Innovative Research \&Development, 3(5), 288-299.

Sauser, B. J., Reilly, R. R., \& Shenhar, A. J. (2009). Why projects fail? How contingency theory can provide new insights-A comparative analysis of NASA's Mars Climate Orbiter loss. International Journal of Project Management, 27(7), 665-679. https://doi.org/10.1016/j.ijproman.2009.01.004

Shapiro, J. (2011). Monitoring and Evaluation. Johannesburg: CIVICUS.

Shrenash, R., Pimplikar, S., \& Sawant, K. (2013). Effect of project cost and time monitoring on progress of construction project. International Journal of Research in Engineering and Technology, 2, 12.

Smith, J., \& Jagger, D. (2010). Technology and Engineering Cost. Planning for Design Team.

Tembo, F. (2003). Participation, negotiation and poverty: encountering the power of images. Designing pro-poor development programmes. Ashgate Publishing Ltd. https://doi.org/10.2307/1914185

Tversky, A., \& Kahneman, D. (1979). Prospect Theory: An analysis of Decision under Risk. Econometrica, 47(2), 263-291.

UNDP. (2009). Capacity Development: a UNDP primer. New York: UNDP.

USAID. (2018). A Report on project management using logistical framework. Washington DC.: USAID., Washington DC.

Waithera, S. L., \& Wanyoike, D. M. (2015). Influence of project monitoring and evaluation on performance of youth funded agribusiness projects in Bahati Sub-County, Nakuru, Kenya. 
International Journal of Economics, Commerce and Management, 3(11), 375.

Wanyonyi, W. K. (2015). Influence of risk management strategies on project performance: a survey of selected international development organisations based in Nairobi City, Kenya. University of Nairobi Student's Research, 31.

\section{Copyright}

Copyright for this article is retained by the author(s), with first publication rights granted to the journal.

This is an open-access article distributed under the terms and conditions of the Creative Commons Attribution license (http://creativecommons.org/licenses/by/4.0/). 